Several studies have suggested that stimulation of the immune system with non-specific agents, including bacteria such as BCG and Corynebacterium parvum, may help to delay or partially suppress the growth of some neoplasms, ${ }^{9-11}$ especially if administered locally. ${ }^{11-13}$ Lung cancers have tumour-associated antigens, ${ }^{14-16}$ but some patients are immunosuppressed and cannot respond. ${ }^{1 ;}$ Khadzhiev and Kavaklieva-Dimitrova ${ }^{1 *}$ administered BCG to patients with carcinoma of the lung and observed radiological evidence of regression in $28^{\circ}{ }_{0}$, of cases and an improvement in survival. Pimm and Baldwin ${ }^{19}$ showed that intrapleural administration of BCG may suppress the pleural growth of transplanted rat tumour. Ruckdeschel et al postulated a mechanism by which the reaction of the immune system, evoked by intrapleural sepsis, may destroy residual cancer cells.

Our findings suggest that any possible suppression of carcinoma cells due to sepsis in the pleural space is inadequate to prolong survival.

We thank Mr Geoffrey Flavell for help and permission to review his patients.

Requests for reprints should be addressed to: Mr Harvey Minasian, 52 Denbigh Road, London W13 $8 \mathrm{NH}$.

\section{References}

Le Roux, B T, British fournal of Surgery, 1965, 52, 89.

Williams, N S, and Lewis, C T, British fournal of Surgery, 1976, 63, 520.

${ }^{3}$ Cady, C, and Clifton, E E, Fournal of Thoracic and Cardiovascular Surgery, $1967, \mathbf{5 3}, 102$.

4 Takita, H, fournal of Thoracic and Cardiovascular Surgery, 1970, 59, 642.

'Ruckdeschel, J C, et al, New England fournal of Medicine, 1972, 287, 1013.

Lawton, R L, and Keehan, R J, Fournal of Surgical Oncology, 1972, 4, 466.

7 Armitage, P, Sequential Medical Trials, 2nd edn, p 41. Oxford, Blackwell Scientific, 1975.

* Feinstein, A R, New England fournal of Medicine, 1968, 279, 747.

${ }^{9}$ Bast, R C, et al, New England fournal of Medicine, 1974, 180, 634.

I" Morton, D L, et al, Annals of Surgery, 1974, 180, 635.

11 Scott, M T, Seminars in Oncology, 1974, 1, 367.

${ }^{12}$ Morton, D L, et al, Annals of Internal Medicine, 1971, 74, 587.

13 Zbar, B, et al, Fournal of the National Cancer Institute, 1972, 49, 112.

14 Tillock, T W, Rosa, J, and Vervynck, D J, fournal of the National Cancer Institute, 1974, 52, 1059.

15 Boddie, A W, et al, International fournal of Cancer, 1975, 15, 823.

${ }^{16}$ Roth, J A, et al, fournal of Thoracic and Cardiovascular Surgery, 1975, 70, 613.

17 Holman, E C, Annals of Thoracic Surgery, 1976, 21, 250.

${ }^{1 *}$ Khadzhiev, A, and Kavaklieva-Dimitrova, Ya, Voprosi Onkologii, 1971, 17, 51 .

19 Pimm, M V, and Baldwin, R W, International fournal of Cancer, 1975, 15, 260.

(Accepted 8 September 1978)

\title{
Trial of high-titre human rubella immunoglobulin
}

\author{
G E D URQUHART, R J CRAWFORD, J WALLACE
}

British Medical fournal, 1978, 2, 1331-1332

\section{Summary and conclusions}

To test the efficacy of passive antibody for protecting susceptible pregnant women who have been exposed to rubella high-titre human rubella immunoglobulin (HRI) was given to 20 seronegative male adult volunteers simultaneously with rubella vaccine. After receiving the intramuscular injections of HRI (750 $\mathrm{mg}$ of IgG) and vaccine $\left(10^{3 \cdot 9:}\right.$ median tissue culture dose, Wistar RA27/3 subcutaneously) eight of the 20 volunteers failed to show seroconversion. Antibody responses-and thus presumably viraemia-in the remaining 12 volunteers were delayed and reduced when compared with those in 19 volunteers given the vaccine alone. No significant responses occurred in volunteers given only HRI.

We conclude that HRI may be of value for seronegative pregnant women who come into contact with clinical rubella, particularly when termination is likely to be refused.

\section{Introduction}

Since laboratory tests for rubella ${ }^{1}$ were introduced several studies $^{2-4}$ have shown that human normal immunoglobulin has no prophylactic or therapeutic value in natural rubella infections. Pepsin-treated human normal immunoglobulin given intravenously ${ }^{5}$ and preparations of high-titre human rubella immunoglobulin $^{6}$ (HRI) given intramuscularly, however, have proved $100 \%$ effective when used for pre-exposure prophylaxis in in-vivo experimental studies. A useful immunising effect was also observed when HRI was given up to three days after experimental intranasal infection. ${ }^{7}$ Shortage of HRI has limited further studies, but as a batch was prepared in 1974 by the protein fractionation centre of the Scottish Blood Transfusion Service we undertook a study to establish whether HRI modifies or prevents rubella infection in susceptible pregnant women who have been exposed to the infection. To simulate the natural infection and its prophylaxis we gave rubella vaccine alone, HRI alone or both simultaneously to rubella-susceptible male adult volunteers and followed them up clinically and serologically (GEDU and RJC) for 12 weeks.

\section{Subjects and methods}

Plasma specimens from about 1500 male blood donors aged under 30 were tested by the haemagglutination inhibition (HI) technique ${ }^{8}$ for rubella antibody, and 52 out of the 238 who were susceptible volunteered to take part in the trial. Susceptible subjects were defined as those who had no detectable antibody on duplicate serum testing at a dilution of 1 in 8 . Similarly, out of 80 male medical students, eight of 12 who were susceptible volunteered. All volunteers were given a detailed explanation of the study before they agreed to participate. None had any contraindication to the vaccine, and though there appear to be no risks from spread of vaccine virus they were advised to avoid close contact with any pregnant woman throughout the 12 -week study period
Glasgow and West of Scotland Blood Transfusion Service, Law Hospital, Carluke, Lanarkshire ML8 5ES

R J CRAWFORD, MB, MRCPATH, consultant

$\mathrm{J}$ WALLACE, FRCPGLAS, FRCPATH, former regional director (retired)




Twenty volunteers received an injection of $0.5 \mathrm{ml} \mathrm{Wistar} \mathrm{RA27/3}$ rubella vaccine (Almevax) subcutaneously into the deltoid region; 20 received $5 \mathrm{ml}$ ( $750 \mathrm{mg}$ protein) $\mathrm{HRI}$ into the gluteal muscle; and 20 were given both injections simultaneously. The vaccine consisted of 40 single doses from the same batch (RB/10/26), each of which contained $10^{3.92}$ median tissue culture dose, and was reconstituted immediately before use. The 40 single doses of HRI ( $750 \mathrm{mg}$ protein) were also from the same batch and were prepared from a pool of hightitre $(\mathrm{HI} \geqslant 256)$ rubella plasma donations. The fractionation method used was a modification of that of Cohn et al, ${ }^{9}$ using cold ethanol precipitation. Immunoglobulin prepared thus does not normally transmit hepatitis B. The HI titre was 260000 , which was 32-64 times higher than that found in four separate batches of human normal immunoglobulin. No rubella-specific IgM antibody was present in the preparation.

Blood specimens were taken immediately before injection and two, four, eight, and 12 weeks later. Sera were tested for HI, complementfixation antibody, and specific rubella $\operatorname{IgM}$ antibody ${ }^{8}$ (this last by sucrose density-gradient fractionation followed by short- and longincubation $\mathrm{HI}$ tests and verified by mercaptoethanol treatment). Each follow-up specimen was tested along with any preceding specimens from the same subject; tests for IgM antibody were carried out before the sera were frozen. Volunteers were asked to record and report any reactions, illnesses, or rubella contact after injection. The study was carried out between October 1977 and early May 1978 to avoid the period of increased natural rubella in the community between spring and autumn.

\section{Results}

One recipient of vaccine only and one of HRI only withdrew from the trial before serological studies could be undertaken. Another defaulter who had received vaccine only is included in the analysis because he showed seroconversion by the second week.

All volunteers who received the vaccine alone had fourfold or greater rises in HI antibody by the fourth week (table I), these titres remaining into the twelfth week. None of the 19 who received HRI

TABLE I-Cumulative number of volunteers having rise in $H I$ antibody at 0,2 , 4,8 , and 12 weeks after injection

\begin{tabular}{|c|c|c|c|c|c|c|c|c|}
\hline \multirow{2}{*}{\multicolumn{3}{|c|}{ Group }} & \multirow{3}{*}{$\begin{array}{c}\begin{array}{c}\text { Total } \\
\text { No in } \\
\text { group }\end{array} \\
19 \\
19 \\
20\end{array}$} & \multicolumn{5}{|c|}{ Weeks after injection } \\
\hline & & & & \multirow[t]{2}{*}{0} & \multirow{2}{*}{$\frac{2}{4}$} & \multirow{2}{*}{$\frac{4}{19}$} & \multirow{2}{*}{$\frac{8}{19}$} & \multirow{2}{*}{$\frac{12}{19}$} \\
\hline $\begin{array}{l}\text { Vaccine alone } \\
\text { HRI alone } \\
\text { Both .. }\end{array}$ & $\begin{array}{l}\cdots \\
\because\end{array}$ & $\begin{array}{l}\ldots \\
\ldots\end{array}$ & & & & & & \\
\hline
\end{tabular}

HI = Haemagglutination inhibition. HRI $=$ High-titre human rubella immunoglobulin.

only had significant rises in antibody or detectable IgM antibody, although five developed transient $\mathrm{HI}$ antibody (titre $1 / 8$ ). Twelve of the 20 volunteers who received both injections had rises in HI antibody by the twelfth week, but these occurred later and were five to nine times smaller than those in the vaccine-only group (tables I and II). Specific IgM antibody was detected significantly less often in those who received both injections $(3 / 20)$ than in those who received the vaccine only (14/19) (table III). The antibody was detected by short- and long-incubation HI methods in four of the 14 who received vaccine only compared with one of the three who received both injections. The one volunteer who had a detectable rise in complement-fixation antibody had received vaccine only.

TABLE II-Geometric mean titres of HI antibody in volunteers who received vaccine alone or vaccine and $H R I$

\begin{tabular}{|c|c|c|c|c|c|}
\hline \multirow{2}{*}{ Group } & \multicolumn{5}{|c|}{ Weeks after injection } \\
\hline & 0 & 2 & 4 & 8 & 12 \\
\hline $\begin{array}{l}\text { Vaccine alone } \\
\text { Vaccine and HRI. }\end{array}$ & $\begin{array}{l}<8 \\
<8\end{array}$ & $\begin{array}{l}7.5 \\
<8 \\
\end{array}$ & $\begin{array}{r}69 \cdot 1 \\
7 \cdot 4\end{array}$ & $\begin{array}{r}105 \cdot 5 \\
20 \cdot 0\end{array}$ & $\begin{array}{l}81 \cdot 7 \\
14 \cdot 7\end{array}$ \\
\hline Reduction & & & $\times 9 \cdot 3$ & $\times 5 \cdot 3$ & $\times 5 \cdot 6$ \\
\hline
\end{tabular}

$\mathrm{HI}=$ Haemagglutination inhibition. HRI $=$ High-titre human rubella immunoglobulin.
TABLE III-Number of sera and volunteers with detectable IgM antibody

\begin{tabular}{|c|c|c|c|c|c|c|c|}
\hline \multirow{2}{*}{ Group } & \multirow{2}{*}{$\begin{array}{c}\text { No } \\
\text { in } \\
\text { group }\end{array}$} & \multicolumn{5}{|c|}{$\begin{array}{c}\text { Sera positive } \\
\text { Weeks after injection }\end{array}$} & \multirow{2}{*}{$\begin{array}{c}\text { Total No of } \\
\text { cases positive } \\
\text { for IgM } \\
\text { antibody }\end{array}$} \\
\hline & & 0 & 2 & 4 & 8 & 12 & \\
\hline $\begin{array}{l}\text { Vaccine alone } \\
\text { HRI alone } \\
\text { Both } \quad . .\end{array}$ & $\begin{array}{l}19 \\
19 \\
20\end{array}$ & & 1 & $\begin{array}{c}13^{*} \\
2\end{array}$ & $\begin{array}{l}6^{*} \\
2\end{array}$ & $1^{*}$ & $\begin{array}{c}14 \\
3+\end{array}$ \\
\hline
\end{tabular}

*Out of 18 sera. +Significant: $\mathrm{P}<0.001$.

Apart from some immediate local discomfort after intramuscular injection the incidence of minor illnesses throughout the trial was not significantly different between the three groups, ranging from nine of the 19 given HRI alone to 12 of those given both injections; the incidence in those given vaccine only was intermediate. Most complaints were of minor respiratory infections, and no contact with clinical rubella was reported. Although vaccine was offered after 12 weeks to the 27 volunteers whose HI antibody titre had not increased, too few took up the offer to permit long-term prophylactic studies.

\section{Discussion}

This severe test of HRI on simultaneous administration of $10^{3 \cdot 92}$ median tissue culture dose rubella vaccine is analogous to a case in which a susceptible woman has acquired the infection four or five days previously and is at the stage just before primary viraemia. Serum antibody responses were completely prevented in $40 \%$ of the volunteers and delayed and reduced in the remainder. Schiff ${ }^{6}$ showed that absence of serum antibody response coincides with lack of detectable viraemia, which is the important source of fetal infection.

Our study has established that this HRI preparation possesses antiviral activity when given after vaccination, thus simulating postexposure prophylaxis, though the effect was incomplete in the group as a whole. In this respect our results are similar to those of Neumann-Haefelin et al. ${ }^{7}$ Schiff ${ }^{6}$ found that a similar preparation was $100^{\circ}{ }_{0}$ effective when given as prophylaxis 24 hours before intranasal challenge. The HRI does not interfere with detection of subsequent antibody responses.

The future use of HRI in clinical practice will depend on its availability and results of further studies to establish its exact role, but currently we recommend it for the few susceptible pregnant women who come into contact with clinical rubella and for whom therapeutic abortion is unacceptable. If such a woman is seronegative at the time of contact serological follow-up for 12 weeks might be necessary to detect subsequent possible asymptomatic infection for prognostic assessment. Because of the possible effect of passive antibody on active immunisation we also recommend that the serum should be tested to confirm vaccine seroconversion if vaccine is given after delivery to recipients of HRI who do not contract natural rubella infection.

We thank the Wellcome Foundation for donating the Almevax vaccine, Dr J Watt of the protein fractionation centre for supplying the HRI, and our volunteers for participating.

\section{References}

1 Parkman, P D, Buescher, E L, and Artenstein, M S, Proceedings of the Society for Experimental Biology and Medicine, 1962, 111, 225.

2 British Medical fournal, 1968, 3, 203.

British Medical fournal, 1970, 2, 497

${ }^{4}$ Forrest, J M, Honevman, M C, and Murphy, A M, Medical fournal of Australia, 1973, 1, 745.

${ }^{5}$ Martin du Pan, R, Koechli, B, and Douath, A, Fournal of Infectious Diseases, 1972, 26, 341 .

${ }^{6}$ Schiff, G M, American fournal of Diseases of Children, 1969, 118, 322.

' Neumann-Haefelin, D, et al, Deutsche medizinische Wochenschrift, 1975, $100,177$.

${ }^{8}$ Grist, N R, et al, Diagnostic Methods in Clinical Virology, 3rd edn. Oxford, Blackwell. In press.

${ }^{9}$ Cohn, E J, et al, fournal of the American Chemical Society, 1946, 68, 459.

(Accepted 14 September 1978) 